\title{
Reviewing Conservative Relationship between Accounting and Corporate Governance Mechanisms
}

\author{
Hashem Valipour ${ }^{1} \&$ Mostafa Sohouli Vahed ${ }^{2}$ \\ ${ }^{1}$ Associate Professor, Department of Accounting, Faculty Members of Islamic Azad University, Firozabad, Iran \\ ${ }^{2} \mathrm{PhD}$ Student of Accounting, Islamic Azad University, Yasuj, Iran \\ Correspondence: Hashem Valipour, Associate Professor, Department of Accounting, Faculty Members of Islamic \\ Azad University, Firozabad, Iran. E-mail: h.valipour@gmail.com
}

Received: March 18, 2017

Accepted: April 27, 2017

Online Published: May 17, 2017

doi:10.5539/ijbm.v12n6p172

URL: https://doi.org/10.5539/ijbm.v12n6p172

\begin{abstract}
This research has the aim of reviewing relationship between some corporate governance mechanisms and conservatism in financial reports. Conservatism is potentially useful for corporate governance in some ways: first it reduce opportunistic engagement of management against itself. Second, it results in management report about loss from selling assets and ceases operation and finally it prevents continuity of management investment in projects with negative net present value. Estimated coefficient of independent variable of ownership concentration is positive and their p-value is less than $5 \%$, so it can be said that there is a positive and significant relationship between ownership concentration and conservative accounting and the first sub-hypothesis is accepted. Estimated coefficient of independent variable of BD (Board of directors) size is positive and its p-value is higher than $5 \%$, so it can be said that there is no significant relationship between BD size and conservative accounting then the second sub-hypothesis is rejected. Estimated coefficient of independent variable of $\mathrm{BD}$ composition is positive and its p-value is less than $5 \%$, so it can be said that there is a positive and significant relationship between $\mathrm{BD}$ composition and conservative accounting then the third sub-hypothesis is accepted. Estimated coefficient of independent variable of shareholder directors is negative and its $p$-value is higher than $5 \%$, so it can be said that there is no significant relationship between shareholder directors and conservative accounting then the forth sub-hypothesis is rejected.
\end{abstract}

Keywords: conservative accounting, corporate governance mechanisms

\section{Introduction}

By developing companies and increasing BD's duties and powers, corporate governance system is increasingly considered. Corporate governance is a set of controlling mechanisms inside and outside company which establishes a good balance between shareholders equities from one side and BD's requirements and powers from the other side. Eventually these mechanisms ensure shareholders and financiers and other beneficiary groups based on payback their investment with a reasonable interest and considering their benefits. Corporate governance mechanisms influences exposed information by company for its shareholders and reduce the possibility of lack of full and desirable exposing or under-valuation information. One of the most effective factors on companies' leadership is their BD who can affect company's operation and their results in different ways. Researches show that in case of more effective control of BD on management, the quality and quantity of reported information by management shall be increased. Whereas shareholders decisions depend on information disposed by them and because the aim of financial reports is cooperating decision making process by beneficiaries such as investors, loaners and government, so information load of annual financial statements has a certain importance (Khos Tinat \& Berari Nokashti, 2006).

Quality improvement of company's disposing causes decreasing information asymmetry which results in less earnings management (Rahimian et al., 2009).

Managers, by different motivation, are about to identify interests more quickly and delay losses. Conservatism is a limitation which takes this ability and this opportunistic trend from managers. In this research it has been investigated the relationship between corporate governance and accounting conservatism of listed companies in Tehran Stock Exchange. 
Conservatism is a practical tool in order to meet the requirements of corporate governance mechanisms or appears in its absence. On the other hand in case of weakness in corporate governance mechanisms where the representation issue is more critical, asking for conservatism is increased or decreased? There are two opponent insights about the relationship between them. First, according to this theory that conservatism causes decreasing unreliability and information asymmetry between different groups, the request for conservatism is increased in circumstances that representation issue is going to be more critical. So the more weak corporate governance structures the more conservatism. The opponent view is that the more corporate governance the better control on management, so there is a trend to apply conservative accounting. First insight and second one are called alternative hypothesis and complementary hypothesis, respectively between corporate governance and accounting conservatism (Chi Yung and others, 2009). In spite of the importance of these two issues and their significant advantages there are little literatures in this matter. So it is valuable to review the relation between conservatism and corporate governance. To respond the question what is the effect of corporate mechanisms improvement on rate of accounting conservatism, we can say it could cooperate users in financial decisions or accounting figures. According to discussed topics, this paper tries to answer this main question? Is there a significant relationship between corporate governance mechanisms and accounting conservatism?

\section{Theoretical Basics}

\subsection{Corporate Governance and Conservatisms}

Corporate governance plays an important role in using conservatisms. Corporate governance is a set of methods which are applied to make sure about effective use of company's assets in the ways which are not against beneficiaries' goals. Strong corporate governance structure results in better control by management, in time production of accounting information and identifying bad news more quickly to aware BD and carrying out required measurements. Conservatism also benefits all above mentioned advantages (Garcia et al., 2005).

BDs play fundamental role in making decisions as well as controlling management is most vital component of corporate governance mechanism (Duellman, 2006).

In recent years conservatism has been considered as a useful tool for BD to fully executive key duties such as determining strategies, multilateral supervision on executive officers and accountability before shareholders and beneficiaries (Joo Ann Ho, 2009).

Conservatism constructs a system which prevents overpayment to managers and any extremist optimism (Watts, 2005).

Lack of conservative accounting system causes managers follow projects with negative net present value to don't report any loss in their sales (Ball, 2001).

After identifying losses more quickly, conservatism helps BD to differentiate between projects with negative net present value and other projects (Ahmad and Duellman, 2007).

Managers conceal losses to prevent their dismissing. Losses and/or accepting projects with negative net present value could make shareholders to dismiss managers. Applying conservatism accelerates identifying losses in time and provides instances from operation ineffectiveness for $\mathrm{BD}$ and shareholders and makes them about pursuing losses and investigating its reasons. Such investigations could result in manager dismissing and removing projects with negative net present value. Because of such confliction between benefits and motivation of managers, shareholders and other founders, corporate governance structure mechanism is applied to reduce representation issues by effective controlling on contracts and management behavior. Research literature in context of corporate governance structure effects on role of independent BD members in reducing representation issues emphasize on controlling and directing CEO's behavior and designing incentives for them (Fama and Jensen, 1983).

As the representation issues will be probably more intensive in incongruence of owners and managers and if conservatism plays a real role in managing representation issues, then it is expected more requests for conservatism after increasing conflict of interest between managers and owners. It may be concluded that corporate governance mechanism like independent BD members or managers' ownership could be considered as a mechanism to maintain shareholders' interests (such as adopted conservatism in accounting methods). Hence companies with more proper corporate governance structure show higher rate of conservatism (Garcia et al., 2005). It means the stronger corporate governance structure the more sensitiveness of revenue to bad news then good news (Basu, 1997). 


\subsection{The Role of Dormant Members of Director (Non-Executive Directors) in Corporate Governance}

$\mathrm{BD}$ is the most important factor in controlling and supervising company's management and preserving shareholders' interests. One of discussed topics in terms of BD is BD composition. There are opponent ideas about who BD composition effects on controlling and consequently on performance. Current literatures show that $\mathrm{BD}$ composition is relevant with representation issues amount. The results show that companies with the bigger $\mathrm{BD}$ and internal managers have more trendsto representation issues. Conversely commercial institutes with small BD and more percentage of dormant members of directors are more connected with shareholders prosperity and commercial institute's performance. Smaller BDs could convince management easier to assign and divide assets, so the size of BD is one of the most effective factors in tax management (Minnick and Noga, 2010).

$\mathrm{BD}$ composition is the ratio of dormant members of directors to total member. The more independent members the less representation issues (Hermalin \& Weisbach, 1991). Contrary toexecutive directors, non-executive directors are independent so they act more effective in their controlling roles. Theoretically when BD is independent and has higher proportion of dormant members, the company's performance will be promoted (Muth \& Donaldson, 1998). Also, more independent BDs are in a better position of leading resources towards tax management because they have a more extensive sight about the company and its performance.

BD composition plays a vital role in corporate governance mechanisms. The more number of independent members, the less mistake and fraud in reports. From the point of representation theory, independent dormant members in BDs and their supervision functions as independent individuals help reducing conflict of interest between shareholders and managers (Rahmani et al., 2010). Under effective corporate governance, management is accountable before $\mathrm{BD}$ and $\mathrm{BD}$ is accountable before shareholders with the aim of creating value (Rezaee, 2004).

\subsection{Conservatism Definition}

Conservatism is capturing accountants' tendency to require a higher degree of verification for recognizing good news such as interest than bad news such as loss. This definition describes conservatism from the point of loss and gain. But another definition is defining accounting conservatism from balancesheet view. According to this sight, conservatism means that when in doubt, accountants should choose the procedure that has less favor effect on shareholders' equity. Third definition of conservatism is based on combination of balance sheet and loss and gain. In this sight, conservatism is an accounting concept which results in decreasing reported retained earnings through subsequent identifying of earnings and more quick identifying costs, under valuation of assets and upper valuation of debts. In this research the third definition is used to calculate conservatism criteria. There is another categorization to define accounting conservatism which is conditional and unconditional conservatism. Conditional conservatism is committed by accounting standards, i.e. identifying loss in time in case of bad news and lack of identifying interest in case of goodnews. For example lower of cost or market (LCM) value or net sale value in inventory assessment is kind of conditional conservatism. This type of conservatism is also called loss and gain or retrospective conservatism. But unconditional conservatism is not obliged by accounting accepted standards. This kind of conservatism is under valuating of assets net book value by predetermined accounting procedures. This type of conservatism is also known as balance sheet and/or futuristic conservatism (BaniMahd, Baghbani, 2009).

\subsection{Conventional Interpretation about Accounting Conservatism}

Some of researchers offer some explanations about conservative reporting. All of them suggest that conservatism has advantages for financial statements users. There always will be the issues resulted from managers opportunistic behaviors in financial reports until accounting criteria and indices are used for reporting management function. In using accounting criteria which are information based for investors, managers act biased to increase their private interest and provides and publishes accounting information based on their benefits. If there is no limitation for this opportunistic behavior then accounting figures in financial reports shall be provided biasedly. But conservatism limits opportunistic and biasedly behavior of managers by obliged them to prove themselves. Actually conservatism compensates biased behavior of managers and delays identifying interest, so net assets and interest shall be under-valued. The mentioned effects shall increase the company's value in contracts, because conservatism limits opportunistic attention of manager against himself and other groups such as shareholders. Company's added value is divided between all groups which have agreement with the company and increases their well-being. In this concept, conservatism is an effective conventional mechanism (Watts, 2003). 


\section{Research Hypotheses Explanation}

First Sub-Hypothesis: There is a significant relationship between ownership concentration and accounting conservatism.

About theoretical relationship between ownership concentration and conservatism, Darjindo et al. (2009) had an extensive research in terms of necessity or non-necessity of applying conservatism in international companies with high ownership concentration. They suggested that it is not necessary to provide conservative financial reports in countries which have strong supporting regulations for shareholders equities and companies' ownership structure has high ownership concentration rate. But in countries with weak supporting regulations especially against minor shareholders and with high ownership concentration, it is severely needed to apply conservative procedures in financial reports.

Second Sub-Hypothesis: There is a significant relationship between BD size and accounting conservatism.

Third Sub-Hypothesis: There is a significant relationship between BD composition and accounting conservatism.

Companies' BD is also one of the other corporate governance mechanisms and according to Fama and Jensen (1983) plays a fundamental role in corporate governance, so that an effective BD leads company's management to apply conservatism procedures to prevent optimistic behavior and increase the risk of legal actions against the company.

Meanwhile the independency of BD members is also an important attribute to assess BD's effectiveness. Previous literatures show that the ratio of independent managers effects on managerial monitoring of preparing financial reports. For example Beekes et al. (2004) and Ahmand and Doellman (2007) found that companies with more proportion of external managers in $\mathrm{BD}$ composition are more conservative; in another study it was specified that high independency of BD members decrease possible Bizly's (1997) scam and Klein's (2002) earnings management (Lim, 2009).

Forth Sub-Hypothesis: There is a significant relationship between managers ownership and accounting conservatism.

$\mathrm{BD}$ is the most important factor in controlling and monitoring company's management and protecting shareholders' interests. One of the discussed topics in terms of BD focuses on BD composition. There are variant opinions about how BD's composition effects on monitoring and consequently on performance. Current literatures indicate that there is a relationship between $\mathrm{BD}$ composition and amount of representation issues. The results show that companies with bigger $\mathrm{BD}$ and internal managers trend more to representation issues. On the contrary commercial institutes with small BD and more non-executive directors have more relationship with shareholders' prosperity and commercial institute's performance. BD with smaller size could convince management to assign and divide assets for tax management, so BD's size is one of the most effective factors on tax management.

$\mathrm{BD}$ composition is seen as ratio of non-executive directors of $\mathrm{BD}$ to total members. The more independent members in BD composition, the less representation issues (Hermalin and Weisbach, 1991). Contrary to executive directors, non-executive directors are independent from company's management and for this reason act more effective in their supervision role. Hence, theoretically when BD is independent and has high proportion of non-executive directors, the company's performance shall be promoted (Muth and Donaldson, 1998). Also more independent BDs are in a better position to direct resources toward tax management because their independency gave them a more extensive insight about companies and its' overall function.

Twofold responsibility of CEO is happened when company's CEO is also elected as chairman of D. This matter could possibly result in conflict of interest and unhanded independency. When CEO is in BD's composition (twofold responsibility), there are less threats to lost the job and this twofold duties causes manager has less motivation to improve function and negative effect on company's performance (Minnick and Noga, 2010). So there will be no measure toward tax management and increasing function by CEO.

Independent accounting is a proper mechanism to control conventional relationship between mangers and shareholders and in most researches about interactions between representation theory and auditing, it has been reviewed the effects of corporate governance mechanisms on possible choice of auditing institutes with high quality. Lin et al. (2009) investigated the effects of corporate governance mechanisms on big auditing institutes. The results showed that monitoring by major shareholders, CEO and chairman being the same (twofold duties) causes decreasing selection of 10 big Chinese auditors. So there is a positive and significant relationship between quality of corporate governance and size of auditing institute. Greater auditing institutes are expected to render better auditing services because of retaining their reputation and experiments, so according to more accurate 
auditing, it suppresses tax management to be done by company.

\section{Research Model and Variables}

To test research hypotheses, research variables are as follows:

Conservative Accounting (CON ACC) which is measured by Gioly and Hayn model (2000)

According to the mentioned model, conservatism index is calculated as follow:

$\mathrm{CON}$ ACC $=$ (operating accrual items/total assets in first period)*(-1)

Operating accrual items are the difference of net income and operating cash flows plus depreciation. According to Gioly and Hayn (2000), growth of accrual items could be an index of changing CON ACC rate in a long-term. On the other hand if accrual items are increased, then conservatism shall be decreased and vice-versa. So to determine the direct of conservatism changes, accrual items are multiplied in a negative number (Gioly and Hayn, 2000). In this research, the conservatism index is the average of these indices during past four years.

The reasons of choosing upper model to measure CON ACC are as follows:

A) Current models such as Basu's one which is extensively used in some local and foreign researches show many errors in measuring conservatism. For example Basu's model supposes that when dividend is negative this matter results from CON ACC, while in Iran capital market, negative dividend results from non-accounting information rather than accounting one (BaniMahd, Baghbani, 2009).

B) The information of applied model in this research is based on accounting information and market indices are not used. According to access financial statements to measure concealed conservatism in financial statements, this model is more proper for under developing markets such as Iran capital market than other models (BaniMahd, Baghbani, 2009).

$\mathrm{BCH}$ (corporate governance): In recent years, corporate governance became a main and dynamic aspect of business and is increasingly considered. Applying corporate governance internationally improved. International organizations such as Organization for Economic Cooperation and Development (OECD) provide acceptable international standards in this matter. In USA and UK also continues to reinforce corporate governance systems and especially consider shareholders and their relationships, accountabilities, BD performance improvement, auditors and accounting systems and internal control as well as methods which applied by companies to control and manage. Furthermore minor investors, institutional investors, accountants, auditors and other players in monetary market scene are aware of philosophy and necessity of constant improvement of corporate governance (HassasYeganeh, 2005).

CONS (ownership concentration) which is calculated according to Herfindahl-Hirschman index

Ownership concentration is how shares divided - (CONS): Variable of ownership concentration between shareholders of different companies. The less number of shareholders, the more concentrate ownership. In this research the ownership concentration is used. The mentioned index is the sum of Herfindahl-Hirschman Index (HHI) and square of share percentage of shareholders. This index increased by ownership concentration rate increasing and if the whole shares belong to one person, takes more value and calculated 10,000 units. If ownership structure is diffused and all shareholders $(10,000 / \mathrm{N})$ are less valued, the Herfindahl index is calculable as follow:

$$
H H I=\sum_{i=1}^{n}\left(\frac{P_{i}}{P} \times 100\right)^{2}
$$

$\mathrm{BD}$ size (BS): which is calculated according to number of $\mathrm{BD}$ members

$\mathrm{BD}$ is one of the main pillars of corporate governance. The main duty of BD is effective leadership of company's affairs along with shareholders' benefits and making balance between different beneficiaries such as customers, personnel, investors and local communities. Fundamental issues of BD are its composition and bonus of CEOs. The characteristics of BD composition include its size and structure, number of BD directors. From the point of representation, it can be said that a bigger BD is more likely to be aware about representation issues because more individuals monitor management duties. When $\mathrm{BD}$ is big, it is more possible to include independent members with valuable specialties. BD expert members are expected to better prevent or limit opportunistic behavior of management (on the other hand, earnings management). Bigger BDs likely delegate their duties to BD committees. By forming sub-committees because of plenty number of BD members, it is more possible to provide more monitoring interest. On the other hand there is negative relationship between BD size and earnings 
management (Aghaee, Chalaki, 832).

So it seems that the BD size increases manipulating real activities and enhances validity of accounting interests.

$\mathrm{BD}$ composition (BC): which is calculated by ratio of number of non-executive directors to total BD members

In part of governance factors, components such as separating $\mathrm{CEO}$ and chairman positions, alignment of shareholders and managers objects, period of CEO and governance necessity in related to BD composition could influence the mentioned composition and its aspects. In this matter Voordeckers et al. (2007) suggest that if CEO is also the chairman, it negatively effects on number of BD independent members. While according to Ning et al. (2008) if the period of CEO takes long, this matter could effects on BD composition. Jaskiewicz and Klein (2007) claim that the more close of managers and shareholders goals, the smaller BD size and less number of independent members.

BD members of companies are executive directors or non-executive. Executive members, more than duties of BD members, physically participate in BD (like CEO position) but non-executive members don't physically participate and just make decisions. In this matter we are going to separate executive and non-executive directors of $\mathrm{BD}$ of corporates.

Ratio of managers' ownership (DS): which is calculated by ratio of shares belong to BD members to total issued shares

Managers' ownership makes more alignment between managers and shareholders interest and decrease representation issues between two sides (Jensen and McLing, 1976). When percentage of managers' ownership is high, however overvaluation of current earnings results in more bonuses for managers, but because of conversion of this fact in future, company's value (and wealth of director as a shareholder) will be deceased in future. Basic of this reasoning is that managers with higher ownership are expected to retain in their position for a long time (Lafond, 2008). Consequently by increasing managers' ownership, their motivations and interests are became more alignment with other shareholders and the representation issue will be less severe.

Financial leverage (LEV): Ratio of debts to total assets

Accounting methods is related to financial leverage because one of the concepts which considered by creditors (loaners; banks in Iran) is the ratio of companies' debts. So the higher debit ratio, the fewer tendencies to conservatism methods. Consequently companies' managers are expected to practice less conservatism in financial statement to reduce possibility of non-acceptance of loan request and prevent higher interest rate. This variable is defined as total debts to total assets at the ending of period.

So the research model shall be as follow:

$$
\text { CONACCit }=\alpha 0+\alpha_{1} \text { CONS }+\alpha_{2} \text { BSit }+\alpha_{3} B C_{i} t+\alpha_{4} \text { DS }+\alpha_{5} \text { Levit }+\varepsilon \text { it }
$$

\section{Research Method}

The population of this research is all listed companies in Tehran Stock Exchange between 2011 and 2015 which required financial information is accessible as financial statements, reports of independent auditors and explanatory notes. In this research, simple random sampling has been used. For this purpose all companies of population which have the following specifications are elected and the rest are omitted:

Table 1. Listed companies in TSE up to Mar. 20, 2012

\begin{tabular}{|c|c|c|}
\hline \multicolumn{2}{|r|}{ Listed companies in TSE up to Mar. 20, 2012} & \multirow{2}{*}{$\frac{472}{(62)}$} \\
\hline 1) & Because of activities nature, should not be investment, intermediary, holding, leasing companies or banks & \\
\hline 2) & Fiscal year doesn’t end at Mar. 20 & $(128)$ \\
\hline 3) & Those companies had more than 3 transaction break during fiscal year and/or during mentioned period their stock & $(107)$ \\
\hline \multicolumn{3}{|c|}{ symbol has been omitted from TSE } \\
\hline 4) & The information of variables is not accessible. & $(89)$ \\
\hline
\end{tabular}

In this research, data was collected by referring TSE and studying financial statements of listed companies during 2011 and 2015. In this matter more than studying financial statements, the information of financial statements in TSE website has also been used. Research variables which related to companies' financial statements have been collected by different resources such as TSE CDs, Stock Exchange organization website, websites of some auditing institutes and phone calls to some auditing institutes. Eviews7 has been used to process information. Corporate governance data which used in test have been manually extracted from annual 
reports. Financial data was extracted from audited financial statements of Islamic Research, Development and Studies website of Stock Exchange Organization to calculate conservatism and also reports of independent auditors in the mentioned website to analyze the matter.

In this research, library method was used to review research literature and background. Panel analysis was used to analyze required data. The most advantage of using panel analysis is controlling homogeneous characteristics and considering people, companies, states and countries separately. Meanwhile cross sectional studies and time series doesn't this inhomogeneous and according to model estimation, it is possible for results to be bias by using these methods (Baltagy, 1995).

\subsection{Model Estimation and Analysis}

In this research, the mentioned models are estimated by using mixed data model. So several companies could be reviewed and analyzed at the same time. Mixed data analysis provides a reach environment of information to develop estimation technics as well as analyzable results. Researchers could apply mixed data in cases which could not be reviewed just by time series or cross sectional. As mentioned in clause 3, in mixed data first F-Limer test was used to choose between panel data and pooled data. If p-value is more than error rate of $5 \%$, pooled data and otherwise panel data will be used.

If data are panels, Hausman Test is used to check if intercept has fixed effects or act randomly in sectional-units structure. If probability of Huasman test is less than 5\%, null hypothesis (random effects) is rejected and fixed effects will be elected.

\subsection{Heteroscedasticity Test}

Homoscedasticity is one of the most important hypotheses of linear regression, so elements of breach $U_{\text {it }}$ which appeared in PRF are homoscedasticity, otherwise are heteroscedasticity. In this research heteroscedasticity test is carried out and the results are showed in following table:

Table 2. Results of heteroscedasticity test

\begin{tabular}{lllll}
\hline & & Bartlett & Levene & Brow-Forsythe \\
\hline Hypothesis & df & 5 & $(5.2544)$ & $(5.2544)$ \\
& p-value & 0.000 & 0.000 & 0.000 \\
\hline
\end{tabular}

As we can see in this research, generalized least squares (EGLS) is used to remove heteroscedasticity according to Bartlett and Levene in regression model.

\subsection{Chow Test}

So to test hypotheses of research, first the fixed effects model is estimated, then to see whether there is a significant statistical difference between these intercepts or not, Chaw test has been used.

$\mathrm{H}_{0}$ : without effects (equation of intercepts) pooled model

$\mathrm{H}_{1}$ : with fixed effects fixed effects model

The results of Chaw test are shown in table 3 .

Table 3. Results of Chaw test

\begin{tabular}{lcc}
\hline CONACCit $=\alpha 0+\alpha_{1}$ CONS + & $\alpha_{2}$ BSit $+\alpha_{3} \mathrm{BC}_{\mathrm{i}} \mathrm{t}+\alpha_{4} \mathrm{DS}+\alpha_{5}$ Levit $+\varepsilon$ it \\
\hline F-Limer & Statistic & $\mathrm{p}$-value \\
Cross-section Chi-square & 0.8298 & 0.000 \\
\hline
\end{tabular}

As we can see in Table 3, according to the p-value, the null hypothesis which means equation of intercepts is rejected. So in this stage, fixed effects model is selected as preferred model.

\subsection{Hausman Test}

In this stage, fixed effects model vs. random effects model is tested for hypotheses which their Chaw test results are based on selecting fixed effects model. To do this the Hausman test is used. So first we should estimate random effects model. Hausman test is drawn up as follow to investigate random effects: 
$\mathrm{H}_{0}$ : There is no correlation between individual effects \& explanatory variables Random effects model

$\mathrm{H}_{1}$ : There is a correlation between individual effects \& explanatory variables fixed effects model

The results of Hausman test are shown in table 4.

Table 4. Results of Hausman test

\begin{tabular}{lcl}
\hline CONACCit $=\alpha 0+\alpha_{1}$ CONS + & $\alpha_{2}$ BSit $+\alpha_{3} \mathrm{BC}_{\mathrm{i}} \mathrm{t}+\alpha_{4} \mathrm{DS}+\alpha_{5}$ Levit $+\varepsilon$ it & \\
\hline & Statistic & p-value \\
Cross-section random & 3.0452 & 0.0030 \\
\hline
\end{tabular}

As we can see in Table 4, p-value is less than 0.05 , so the $\mathrm{H}_{1}$ hypothesis which based on correlation between individual effects and explanatory variables is accepted. So to estimate the model, fixed effects method is used.

\subsection{Testing Hypotheses According to Determined Models}

The models have been estimated according to the results of Chaw test and Hausman test tables in accordance with dependent variable.

Hypothesis: There is a significant relationship between corporate governance mechanisms and accounting conservatism.

According to the above hypothesis, statistical hypothesis of the research has been classified as follows:

$\mathbf{H}_{\mathbf{0}}$ : There is a significant relationship between corporate governance mechanisms and accounting conservatism.

$\mathbf{H}_{\mathbf{1}}$ : There is no significant relationship between corporate governance mechanisms and accounting conservatism.

The results of above mentioned hypothesis by using EGLS method are shown in table 5 .

Table 5. Results of first hypothesis estimation

\begin{tabular}{lllll}
\hline CONACCit $=\alpha 0+\alpha_{1}$ CONS + & $\alpha_{2}$ BSit $+\alpha_{3} \mathrm{BC}_{\mathrm{i}} \mathrm{t}+\alpha_{4} \mathrm{DS}+\alpha_{5}$ Levit $+\varepsilon$ it & & \\
Variables & & $\mathrm{p}$-value & T statistic & Coefficient of variation \\
\hline Ownership concentration & $\mathrm{CONS}$ & 0.02 & 2.26 & 0.01 \\
BD size & $\mathrm{BS}$ & 0.19 & 1.28 & 0.29 \\
BD composition & $\mathrm{BC}$ & 0.03 & 1.19 & 0.06 \\
Shareholder managers & $\mathrm{DS}$ & 0.43 & -0.78 & -0.002 \\
Leverage & LEV & 0.01 & -0.36 & -0.01 \\
Durbin-Watson test & & & 2.36 & \\
Coefficient of determination & & & 0.30 & \\
Probability of F statistic & & & 0.00 & \\
\hline
\end{tabular}

As we can see in table 5, estimated coefficients of the independent variables of ownership concentration are positive and its p-value is less than 5\%. So it can be said that there is a positive and significant relationship between ownership concentration and accounting conservatism and the first sub-hypothesis of the research is accepted.

Estimated coefficients of the independent variables of $\mathrm{BD}$ size are positive and its p-value is bigger than $5 \%$. So it can be said that there is no significant relationship between BD size and accounting conservatism and the second sub-hypothesis of the research is rejected.

Estimated coefficients of the independent variables of BD composition are positive and its p-value is less than $5 \%$. So it can be said that there is a positive and significant relationship between BD composition and accounting conservatism and the third sub-hypothesis of the research is accepted.

Estimated coefficients of the independent variables of shareholder managers are negative and its $p$-value is bigger than $5 \%$. So it can be said that there is no significant relationship between shareholder managers and accounting conservatism and the forth sub-hypothesis of the research is rejected.

Also coefficient of determination of this model is $0.30 \%$ according to independent variable of healthy companies. This measure shows that $0.30 \%$ of the changes of dependent variable are explainable by mentioned independent 
variables. Whereas Durbin-Watson statistic is 2.36 , it can be said that there is no first-order autocorrelation in this model. Furthermore the results show that the probability of F-statistic is less than $5 \%$, so it can be said that the probability of being significant of this model is $95 \%$ and has high validation.

\section{Discussion and Conclusion}

Conservatism is one of characteristics of financial reports which plays an important role in framework of accounting principles and concepts to limit opportunistic behaviors of managers in the position of information provider and who gives an estimation of minimum earnings by investors and loaners. The researches about conservatism indicate the importance of its role in accounting convention in different fields such as removing representation issues, nullifying issues resulted from information asymmetry between aware and unaware users, vindication of the rights of company's beneficiaries, positive effects of decreasing borrowing and capital costs, deterrent role against financial scandals and also its undeniable role in corporate governance (Watts 23, 2003).

Estimated coefficients of the independent variables of ownership concentration are positive and its p-value is less than $5 \%$. So it can be said that there is a positive and significant relationship between ownership concentration and accounting conservatism and the first sub-hypothesis of the research is accepted.

Estimated coefficients of the independent variables of BD size are positive and its p-value is bigger than $5 \%$. So it can be said that there is no significant relationship between BD size and accounting conservatism and the second sub-hypothesis of the research is rejected.

Estimated coefficients of the independent variables of BD composition are positive and its p-value is less than $5 \%$. So it can be said that there is a positive and significant relationship between BD composition and accounting conservatism and the third sub-hypothesis of the research is accepted.

Estimated coefficients of the independent variables of shareholder managers are negative and its p-value is bigger than $5 \%$. So it can be said that there is no significant relationship between shareholder managers and accounting conservatism and the forth sub-hypothesis of the research is rejected.

\section{References}

Abdelghany, K. E. (2005). Measuring the Quality of Earnings. Managerial Auditing Journal, 20(9). 1001-1015.

Ahmed, A. S., \& Duellman, S. (2007). Accounting Conservatism and Board of Director Characteristics: An Empirical Analysis. Journal of Accounting and Economics, 43(2-3), 411-437.

Ball, R., \& Shivakumar, L. (2005). The Role of Accruals in Asymmetrically, Timely Gain and Loss Recognition. Working paper, university of Chicago.

Basu, S. (1997). The Conservatism Principle and the Asymmetric Timeliness of Earnings. Journal of Accounting and Economics, 24(1), 3-37

Bello, A. (2011). Corporate governance and accounting ethics in Nigeria.

Chu, Y. L., AsadKausar, E. L., \& Martin, W. (2011). Bank accountingconservatism, lending behavior and credit crises. Manchester Business School.

Donglin, X., \& Song, Z. (2009). Corporate Governance and accounting conservatism in China. China Journal of Accounting Research, 2(2).

Duellman. (2004). Evidence of the role of conservatism in corporate governance.

Garcia, L. J. M., Garcia, O. B., \& Penalva, F. (2005). Board of directors characteristics and conditional accounting conservatism: Spanish evidence. University of Navarra, Av. Pearson, 21, 08034 Barcelona, Spain.

Garcia, L. J. M., Garcia, O. B., \& Penalva. F. (2007). Accounting conservatism and corporate governance. Universidad Carlos III de Mardrid Spain.

Garcia, L., \& Beatriz, G. O., \& Fernando, P. (2009). Board of Directors Characteristics and Conditional Accounting Conservatism: Spanish Evidence. Universidad Carlos III de Madrid Spain.

Garcia, L., Beatriz, G. O., \& Penlva, F. (2009). Board of Directors Characteristics and Conditional Accounting Conservatism: Spanish Evidence. Universidad Carlos III de Mardrid Spain.

Givoly, D., \& Hayn, C. (2000). The changing time-series properties of earnings, cash flows and accruals: Has financial reporting become more conservative? Journal of Accounting \& Economics, 29(3), 287-320.

JooAnn. H. (2009). Association between board characteristics and accounting conservatism. Auckland 
University of Technology, Malaysia.

Mahdavi, A., \& Midary, A. (2005). Ownership structure and effectiveness of active TSE listed companies. Economic Research Journal, 71, 103-132

Mehran, K., Hallaj, M., \& Hassani, A. (2009). Reviewing accounting income conservatism and its relationship with accrual rules in TSE. Accounting Research Quarterly, 3, 88-107.

Mohammed, M. H., Hasan, A., \& Hosni, A. A. (2011). Factors Influencing Accounting Conservatism in the Financial Statements. Alia University, Bahrain.

Noorvash, I., Karami, G., \& VafiSani, J. (2009). Review of leadership system mechanism of representatives of TSE listed companies. Accounting Research Quarterly, 1, 27.

Nor, F., Kamran, A. \&X, D. J. (2011). Accounting conservatism, corporate governance and political influence. School of Accounting, La Trobe University, Australia.

Poor, H. O., \& Hemati, D. (2004). Review of effects of debit contracts, political expenses, bonus plans and ownership of interest management in TSE listed companies. Accounting and Auditing Reviews, 36, 47-63.

Qintao, F., \& Zhang, X. J. (2006). Accounting Conservatism, Aggregation, and Information Quality. University of California.

Rah, C. (2006). Role of ownership structure and rate of supporting shareholders equity. Asia quarterly, 30, 36;

Rahimah, M. Y. (2011). The effect of ownership concentration, board of directors, audit committee and ethnicity on conservative accounting. Edith Cowan University, Malaysia.

Sanda, A. U., Mikailu, A. S., \& Garba, T. (2004). Director Shareholding, Board Size and Firm Performance of Firms in Nigerian Stock Exchange. Nigerian Journal of Accounting Research, Department of Accounting, Ahmadu Bello University, Zaria. Vol1, Number 1, June2004.

Sanjay, B. (2010). A Framework for Conservatism and Measurement in Financial Reporting. University of Amsterdam.

Shuping, C., Xia, C., Qiang, C., \& Amy, H. (2009). Accounting Conservatism and Large Shareholders. University of Texas, Austin.

Wang, Z. R. (2009). Accounting Conservatism. Victora University of Wellington.

Watts, R. (2002). Conservatism in Accounting. Simon School of Business, University of Rochester.

Wuchun, C., Chiawen, L., \& Taychang, W. (2009). What affects Accounting Conservatism: A Corporate Governance Perspective. National Taiwan University, Taiwan.

Xi, L. (2010). Accounting conservatism and the cost of capital: International Analysis. London Business School.

Xu, J. G., \& Lu, C. J. (2008). Accounting Conservatism: A Study of market-level and firm level-explanatory factors. China Journal of Accounting Research, 1.

Young, K. K. (2005). Accounting conservatism and managerial incentives. Managerial Science, 51, 1626-1632

Zhang, J. (2008). The Contracting Benefits of Accounting Conservatism to Lenders and Borrowers. Journal of Accounting and Economics, 45, 27-54.

\section{Copyrights}

Copyright for this article is retained by the author(s), with first publication rights granted to the journal.

This is an open-access article distributed under the terms and conditions of the Creative Commons Attribution license (http://creativecommons.org/licenses/by/4.0/). 